\title{
Natural radiation exposure to the public in the oil-bearing Bakassi Peninsula, Cameroon
}

\author{
Saïdou $^{1,2 \star}$, Abdourahimi ${ }^{1,2,3}$, Y.F. Tchuente Siaka ${ }^{2}$ and M.G. Kwato Njock ${ }^{3}$ \\ 1 Nuclear Technology Section, Institute of Geological and Mining Research, P.O. Box 4110, Yaoundé, Cameroon. \\ 2 Nuclear Physics Laboratory, Faculty of Science, University of Yaoundé I, P.O. Box 812, Yaoundé, Cameroon. \\ 3 Centre for Atomic Molecular Physics and Quantum Optics, Faculty of Science, University of Douala, P.O. Box 8580, Douala, Cameroon.
}

Received 10 May 2014 - Accepted 18 August 2014

\begin{abstract}
The objective of the present study was to carry out natural radioactivity measurements and corresponding dose assessment in the Bakassi Peninsula, an oil-bearing area located in the Gulf of Guinea. This pilot study required E-perm Electret Ionization Chamber (EIC) exposure in homes and the sampling of soils and foodstuffs representative of the food consumption patterns of the population of Bakassi. The results show high exposure of members of the public to natural radiation. Elevated indoor radon concentrations due to building construction were observed, and high exposure to ${ }^{210} \mathrm{Po}$ attributable to the dietary habits of the local population, mainly consisting of seafood. Finally, a total dose of $34.6 \mathrm{mSv} \cdot \mathrm{y}^{-1}$ was found, much higher than the world average value. In the case of confirmation of the results of this study, countermeasures must be taken into consideration to avoid such a high level of exposure, to reduce the radiation dose to the population. Taking into account the limited number of samples, the present work should be considered as a preliminary study.
\end{abstract}

Keywords: oil-bearing region / indoor radon / polonium-210 / lead-210 / seafood

\section{Introduction}

Human exposure occurs by irradiation from sources (cosmic and terrestrial rays) outside the body and upon the decay of radionuclides taken into the body through internal exposure. In terms of dose, the principal primordial radionuclides are ${ }^{40} \mathrm{~K}$, ${ }^{232} \mathrm{Th}$ and ${ }^{238} \mathrm{U}$ series (UNSCEAR, 1993, 2000). Several studies on natural radioactivity and corresponding dose assessment have been carried out in Cameroon. Saïdou et al. (2011) reported radioactivity measurements and total dose assessment in the uranium region of Poli. Most of the dose assessed is attributable to the intake of radon and high levels of ${ }^{210} \mathrm{Po}$ and ${ }^{210} \mathrm{~Pb}$ contained in vegetables, food items which constitute an important part of the diet in Northern Cameroon. Consequently, bringing uranium ore from underground to the surface might lead to an increased dose for the population of Poli through a higher deposition of ${ }^{222} \mathrm{Rn}$ decay products on leafy vegetables. Indoor radon measurements were extended in the uranium regions of Poli and Lolodorf (Saïdou et al., 2014). Results show that $20 \%$ of houses in Poli and $50 \%$ in Lolodorf have indoor radon above the reference level at $300 \mathrm{~Bq} / \mathrm{m}^{3}$ (WHO, 2009), requiring radon mitigation. Ele Abiama et al. (2010) and Beyala Ateba et al. (2011) studied the high background radiation and internal/external radiation exposure to the public of the uranium region of Lolodorf. These studies

\footnotetext{
* saidous2002@yahoo.fr
}

evidenced high radioactivity occurring in this region. Ngachin et al. (2007) reported a study on external radiation exposure from building materials used in Cameroon. This study concluded that all the materials examined are acceptable for use as building materials as defined by the Organization for Economic Cooperation and Development criterion (OECD, 1979).

The Bakassi Peninsula, located in the hollow of the Gulf of Guinea, is rich in oil and fish stocks and has several offshore production platforms, which could lead to the environmental pollution of the area by Naturally Occurring Radioactive Materials (NORM) (ICJ, 2002). Reported studies concluded that materials found in the downhole and surface structures of oil and gas production facilities do not include ${ }^{238} \mathrm{U}$ and ${ }^{232} \mathrm{Th}$ (Jonkers et al., 1997; IAEA, 2003). These elements are not mobilized from the reservoir rock that contains the oil, gas and formation water. The formation water contains Group II (Periodic Table) cations of calcium, strontium, barium and radium dissolved from the reservoir rock. As a consequence, formation water contains the radium isotopes ${ }^{226} \mathrm{Ra},{ }^{228} \mathrm{Ra}$ and ${ }^{224} \mathrm{Ra}$.

The aim of the present study is to carry out radioactivity monitoring and to assess the corresponding dose for the inhabitants of the Bakassi Peninsula. An E-perm Electret Ionization Chamber (EIC) was used for the measurement of radon exposure in homes. Sampling of soils and foodstuffs representative of the food consumption patterns was performed to assess the 


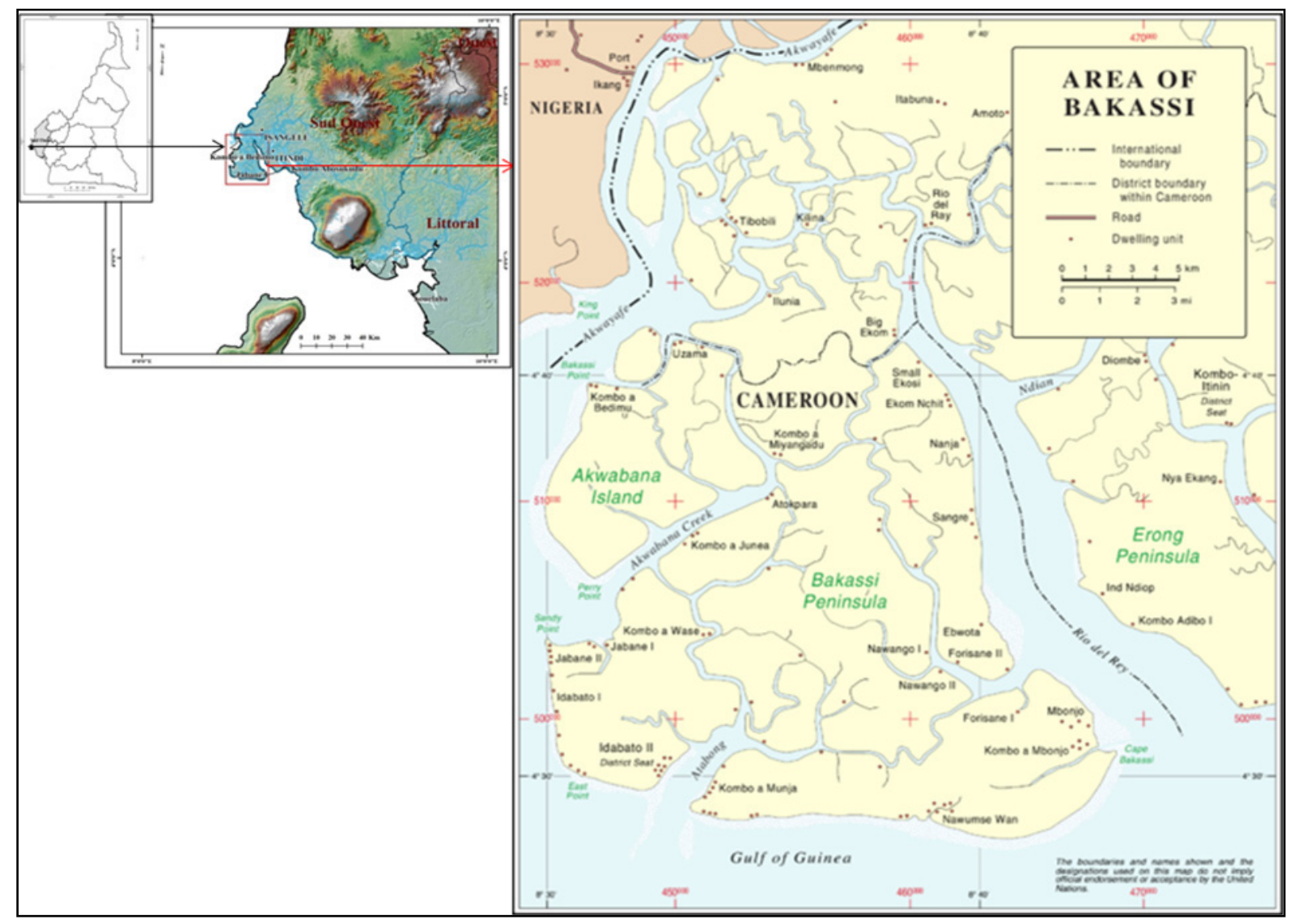

Fig. 1. Location of the Bakassi Peninsula in the Gulf of Guinea.

corresponding radiation dose of the local population. Because of the limited number of samples analyzed, this work should be considered as a pilot study.

\section{Material and methods}

\subsection{Area of study and sampling}

The Bakassi peninsula is situated in the hollow of the Gulf of Guinea and is bounded by the River Akwayafe to the West and by the Rio del Rey to the East (Fig. 1). It is an amphibious environment, characterized by an abundance of water, fish stocks and mangrove vegetation (ICJ, 2002). The localities of Jabane, I, II and Idabato I, II were considered for sampling. Respectively, about 5000 and 6000 people live in Jabane and Idabato. The landscapes are the same for the total area of the peninsula. The inhabitable areas where sampling was carried out are surrounded by the sea (Fig. 1). A random method was chosen for soil sampling. Each sample was collected from the top $5 \mathrm{~cm}$ of a $1-\mathrm{m}^{2}$ area, and provided a dry mass of about $500 \mathrm{~g}$. In total, 15 soil samples were collected. In addition, 10 foodstuff samples (leafy vegetables, dried fish and shrimps, etc.) were collected in Jabane and Idabato. Most of the foodstuffs except seafood come from Nigeria because the salty and sandy soil of Bakassi is not adapted to agriculture. Fishing is the main activity of the local population of this part of Bakassi.
Most of the fishers come from Nigeria and other West African countries.

All the soil and foodstuff samples gathered were dried, sieved and homogenized. Conditioned soil samples were kept in Marinelli beakers, hermetically sealed to avoid radon escape. This ensures secular equilibrium between ${ }^{226} \mathrm{Ra}$ and its progeny (Saïdou et al., 2008).

\subsection{Radioactivity measurements}

\subsubsection{Alpha spectrometry $\left({ }^{210} \mathrm{Po}\right)$ for foodstuff samples}

The procedure used for measuring ${ }^{210} \mathrm{Po}$ is based on microwave digestion under pressure for sample mineralization. After spontaneous deposition on a silver disk, polonium sources were measured using Passivated Implanted Planar Silicon (PIPS) detectors with an active area of $450 \mathrm{~mm}^{2}$ in a Canberra Alpha Analyst Spectrometer. The procedure is fully described in (Saïdou et al., 2007).

\subsubsection{Gamma spectrometry using a HPGe detector for foodstuff samples}

Gamma spectrometry measurements in foodstuff samples were performed with a Canberra p-type HPGe well detector (GCW4523) with a total active volume of $206 \mathrm{~cm}^{3}$, a relative photopeak efficiency of $45 \%$, and a resolution at 122 
and $1332 \mathrm{keV}$ of 1.24 and $1.93 \mathrm{keV}$, respectively, as described in (Saïdou et al., 2007). Semadeni D5 geometry $(40 \mathrm{ml})$ was used for the counting time, ranging between 170000-450000 seconds. ${ }^{214} \mathrm{Bi}$ and ${ }^{214} \mathrm{~Pb}$ were used to determine activity concentrations of ${ }^{226} \mathrm{Ra}$ after reaching secular equilibrium between ${ }^{222} \mathrm{Rn}$ and its daughter products.

\subsubsection{Gamma spectrometry using a Nal detector for soil samples}

Gamma spectrometry measurements of soil samples were performed with a Canberra $\mathrm{NaI}(\mathrm{Tl})$ detector (Model 802) with a crystal size of $7.6 \mathrm{~cm} \times 7.6 \mathrm{~cm}$ and a resolution of $7.5 \%$ at $662 \mathrm{keV}$. This Model 802 plugs directly into the Model 2007 Tube Base which provides power for the photomultiplier tube. Treatment of the data was carried out using GENIE 2000 software. The spectrometer was calibrated using a customer-supplied 500-ml Marinelli Beaker containing ${ }^{155} \mathrm{Eu}$, ${ }^{57} \mathrm{Co},{ }^{113} \mathrm{Sn},{ }^{137} \mathrm{Cs},{ }^{54} \mathrm{Mn}$ and ${ }^{65} \mathrm{Zn}$ traceable to international standards and emitting gamma-rays in the energy range of 60-1115.5 keV. The same geometry was used for the counting time of 172800 seconds to measure radioactivity in soil samples. Gamma-lines of ${ }^{214} \mathrm{Bi}$ were used to determine ${ }^{226} \mathrm{Ra}$ activity concentrations after reaching secular equilibrium between ${ }^{222} \mathrm{Rn}$ and its daughter products ${ }^{214} \mathrm{Bi}$ and ${ }^{214} \mathrm{~Pb}$. Gamma-lines of ${ }^{228} \mathrm{Ac}$ were considered to determine activity concentrations of ${ }^{232} \mathrm{Th}$.

\subsubsection{Indoor radon measurements}

The EICs were manufactured by Rad Elec Inc., 5714-C Industry Lane, Frederick, MD 21704, USA. Detailed descriptions of their design and operation are given in the Rad Elec Manual (Kotrappa et al., 1996). An EIC for monitoring radon consists of a stable electret (electrically charged Teflon $囚$ disc) mounted inside an electrically conducting chamber. The electret serves both as a source of the electric field and as a sensor. The ions produced inside the chamber are collected by the electret. The reduction in charge of the electret is related to total ionization during the period of exposure. This charge reduction is measured using a battery-operated Electret Voltage Reader. Using appropriate calibration factors and the exposure time, the desired parameters such as the airborne radon concentration in air is calculated. Normally, the temperatures, humidity and mechanical shocks encountered do not affect the performance of the EICs, making them robust for field use. More details are given in (Saïdou et al., 2014).

Fifteen EICs were exposed in dwellings of Jabane and Idabato for three months, relatively far from the open access (windows, door) of dwellings at $1 \mathrm{~m}$ above the ground to avoid biased measurements due to the influence of outdoor air.

\subsection{Dose assessment}

\subsubsection{External radiation dose}

The radiation exposure from external sources results from natural and artificial ground radiation as well as from cosmic background. The conversion coefficients used to determine the
Table 1. Air kerma conversion coefficients $[(\mathrm{nGy} / \mathrm{h}) /(\mathrm{Bq} / \mathrm{kg})]$ of radioactivity in soil.

\begin{tabular}{cc}
\hline Radionuclides & $\begin{array}{c}\text { Air kerma conversion coefficient of } \\
\text { radioactivity in soil }\left(\mathbf{n G y \cdot h} \mathbf{~}^{-\mathbf{1}}\right) /\left(\mathbf{B q} \cdot \mathbf{k g}^{\mathbf{- 1}}\right)\end{array}$ \\
\hline${ }^{238} \mathrm{U}$ series & 0.46 \\
${ }^{232} \mathrm{Th}$ series & 0.60 \\
${ }^{40} \mathrm{~K}$ & 0.042 \\
\hline
\end{tabular}

radiation dose from natural series of ${ }^{238} \mathrm{U},{ }^{232} \mathrm{Th}$ and for ${ }^{40} \mathrm{~K}$, are listed in Table 1 (UNSCEAR, 2000).

A conversion coefficient of $0.7 \mathrm{mSv} \cdot \mathrm{mGy}^{-1}$ was used to determine the corresponding effective annual dose (UNSCEAR, 1993). In order to combine indoor and outdoor dose rates to calculate the total external dose, we used an indoor occupancy factor of 0.6 , which implies that people spend $40 \%$ of the time outdoors. However, since the materials used in the construction of most of these buildings also contain radionuclides, the average factor of 1.4 was applied to take into account their contribution and estimate the indoor dose rate (UNSCEAR, 2000).

Exposure to cosmic rays is strongly dependent on altitude and weakly dependent on latitude. Analytical expressions have been developed for the general relationship between the annual dose and altitude for both the directly and indirectly ionizing components. In order to combine indoor and outdoor dose rates to compute the cosmic ray dose, an indoor occupancy factor of 0.6 was assumed. Cosmic rays are also attenuated by 20\% indoors (UNSCEAR, 1993, 2000).

$$
\begin{aligned}
\mathrm{E}_{\mathrm{I}}(\mathrm{z}) & =\mathrm{E}_{\mathrm{I}_{0}}\left[A_{I} e^{-\alpha_{I} z}+B_{I} e^{\beta_{I} z}\right] \\
\mathrm{E}_{\mathrm{N}}(z) & =\mathrm{E}_{N_{0}} e^{\alpha_{N} z}
\end{aligned}
$$

where $\mathrm{E}_{\mathrm{I}}$ is the effective dose rate in $\mu \mathrm{Sv} \cdot \mathrm{yr}^{-1}$ for the directly ionizing component; $\mathrm{E}_{\mathrm{I}_{0}}$ is the reference value at sea level, $240 \mu \mathrm{Sv}^{-1} \mathrm{y}^{-1} ; z$ is the altitude in $\mathrm{km} ; \mathrm{A}_{\mathrm{I}}=0.21 ; \alpha_{\mathrm{I}}=1.6 \mathrm{~km}^{-1}$; $B_{\mathrm{I}}=0.80 ; \beta_{I}=0.45 \mathrm{~km}^{-1} ; \mathrm{E}_{\mathrm{N}}$ is the effective dose rate in $\mu \mathrm{Sv}^{-1} \mathrm{y}^{-1}$ for the indirectly ionizing component from neutrons and $\mathrm{E}_{\mathrm{N}_{0}}=30 \mu \mathrm{Sv} \cdot \mathrm{y}^{-1} ; \alpha_{\mathrm{N}}=1.0 \mathrm{~km}^{-1}$.

\subsubsection{Ingestion and inhalation dose}

The ingestion conversion coefficients used in the present work are taken from ICRP Publication 67 (1994) and ICRP Publication 69 (1995). The ingestion dose for each radionuclide is given by the product of the annual ingested activity and corresponding ingestion conversion coefficient. The total ingestion dose is calculated by summing all the contributions of radionuclides.

The inhalation dose is given by the product of the average indoor radon concentration of the studied area and the updated inhalation conversion coefficient of radon given in ICRP Publication 115 (2010).

\section{Results and discussion}

\subsection{Radioactivity in soil and corresponding external radiation dose}

As displayed in Figure 2, activity concentrations in soil samples range between $15.6-23.2 \mathrm{~Bq} \cdot \mathrm{kg}^{-1}$ for ${ }^{226} \mathrm{Ra}$, 
Table 2. Activity concentrations of ${ }^{226} \mathrm{Ra},{ }^{210} \mathrm{~Pb},{ }^{210} \mathrm{Po}$ and ${ }^{40} \mathrm{~K}$ in the main items of food consumed in Jabane and Idabato. ${ }^{226} \mathrm{Ra}$ and ${ }^{210} \mathrm{~Pb}$ activity concentrations are lower than the minimum detectable concentrations (MDC) using $\gamma$-spectrometry.

\begin{tabular}{cccccc}
\hline Sample identifier & Sample & ${ }^{\mathbf{2 2 6}} \mathbf{R a}\left(\mathbf{B q} \cdot \mathbf{k g}^{\mathbf{- 1}}\right)$ & ${ }^{{ }^{\mathbf{1 0}} \mathbf{P b}} \mathbf{( B q \cdot \mathbf { k g } ^ { - \mathbf { 1 } } )}$ & ${ }^{\mathbf{2 1 0}} \mathbf{P o}\left(\mathbf{B q} \cdot \mathbf{k g}^{\mathbf{- 1}}\right)$ & ${ }^{\mathbf{4 0}} \mathbf{K}\left(\mathbf{B q} \cdot \mathbf{k g}^{\mathbf{- 1}}\right)$ \\
\hline GRE-11-136 & Cowpea & $<1.5$ & $<23$ & $0.72 \pm 0.04$ & $359 \pm 8$ \\
GRE-11-137 & White tapioca & $<3.3$ & $<14$ & $0.63 \pm 0.04$ & $111 \pm 10$ \\
GRE-11-143 & Yellow tapioca & $<4.5$ & $<20$ & $0.33 \pm 0.05$ & $147 \pm 15$ \\
GRE-11-138 & Fish & $<3$ & $<21$ & $27.5 \pm 0.8$ & $258 \pm 14$ \\
GRE-11-140 & Fish & $<6$ & $<64$ & $21.6 \pm 0.8$ & $226 \pm 15$ \\
GRE-11-141 & Fish & $<5$ & $<20$ & $14.3 \pm 0.7$ & $271 \pm 13$ \\
GRE-11-139 & Shrimps & $<5$ & $<45$ & $122 \pm 4$ & $237 \pm 13$ \\
GRE-11-142 & Waterleaf & $<6$ & $1.6 \pm 0.3$ & $2.7 \pm 0.2$ & $1880 \pm 32$ \\
GRE-11-144 & Eru leaf & $<25$ & & $14.5 \pm 0.5$ & $1063 \pm 77$ \\
\hline
\end{tabular}

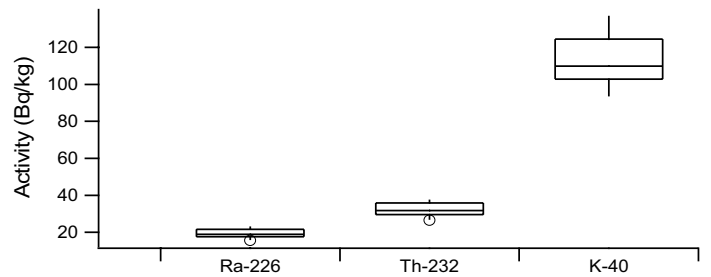

Fig. 2. Radionuclide concentrations in soil samples.

26.5-37.8 Bq. $\mathrm{kg}^{-1}$ for ${ }^{232} \mathrm{Th}$, and $93-138.2 \mathrm{~Bq} \cdot \mathrm{kg}^{-1}$ for ${ }^{40} \mathrm{~K}$. The corresponding average activity is $19 \mathrm{~Bq} \cdot \mathrm{kg}^{-1}$ for ${ }^{226} \mathrm{Ra}$, $32 \mathrm{~Bq} \cdot \mathrm{kg}^{-1}$ for ${ }^{232} \mathrm{Th}$ and $110 \mathrm{~Bq} \cdot \mathrm{kg}^{-1}$ for ${ }^{40} \mathrm{~K}$, respectively. As reported by Agbalagba and Onoja (2011), the mean activity level of ${ }^{226} \mathrm{Ra},{ }^{232} \mathrm{Th}$ and ${ }^{40} \mathrm{~K}$ in soil, sediment and water samples in four flood-plain lakes of the Niger Delta quite close to the Bakassi Peninsula is, respectively, $20 \mathrm{~Bq} \cdot \mathrm{kg}^{-1}, 20 \mathrm{~Bq} \cdot \mathrm{kg}^{-1}$ and $180 \mathrm{~Bq} \cdot \mathrm{kg}^{-1}$

These values are lower than the average activity concentrations observed in the world: $38 \mathrm{~Bq} \cdot \mathrm{kg}^{-1}$ for ${ }^{238} \mathrm{U}, 45 \mathrm{~Bq} \cdot \mathrm{kg}^{-1}$ for ${ }^{232} \mathrm{Th}$ and $420 \mathrm{~Bq} \cdot \mathrm{kg}^{-1}$ for ${ }^{40} \mathrm{~K}$ (UNSCEAR, 2000). The level of natural radioactivity is in agreement with what can be expected when there is no contamination. Finally, no radioactive contamination is evidenced due to the presence of offshore production platforms in the Bakassi Peninsula. The corresponding annual external radiation is $0.27 \mathrm{mSv}^{-1}$ for terrestrial radiation and $0.27 \mathrm{mSv} \cdot \mathrm{y}^{-1}$ for cosmic radiation.

\subsection{Radioactivity in foodstuffs and corresponding ingestion dose}

Table 2 shows activity concentrations of ${ }^{226} \mathrm{Ra},{ }^{210} \mathrm{~Pb},{ }^{210} \mathrm{Po}$ and ${ }^{40} \mathrm{~K}$ in the main items of food consumed in Bakassi. The results show high variability of these radionuclides in foodstuffs. Activity concentrations of ${ }^{210}$ Po range, respectively, between $0.33-122 \mathrm{~Bq} \cdot \mathrm{kg}^{-1}$. The derived product of cassava (tapioca) and cowpea have the lowest activity concentrations, while meat, fish, shrimps and leafy vegetable samples such as Eru leaves have the highest activity concentrations of ${ }^{210} \mathrm{Po}$.

${ }^{226} \mathrm{Ra}$ and ${ }^{210} \mathrm{~Pb}$ activity concentrations are lower than the Minimum Detectable Concentrations (MDC) using gamma spectrometry, as indicated in Table 2. Probably gamma spectrometry is not sensitive enough for activity concentrations in foodstuffs (Saïdou et al., 2008). Moreover, the small quantity of samples collected for measurements, leading to the use of Semadeni D5 $(40 \mathrm{ml})$ instead of more voluminous containers $(250 \mathrm{ml}$ or $500 \mathrm{ml})$, also contributed to making the activity concentrations of ${ }^{226} \mathrm{Ra}$ and ${ }^{210} \mathrm{~Pb}$ below the MDC. Alpha spectrometry is strongly advisable for radioactivity in foodstuffs because of its low detection limit (Saïdou et al., 2008).

${ }^{210} \mathrm{Po}$ activity concentrations range from 14.3-27.5 Bq. kg ${ }^{-1}$ in three species of fish and $122 \mathrm{~Bq} \cdot \mathrm{kg}^{-1}$ in shrimps. ${ }^{210} \mathrm{~Pb}$ and ${ }^{210} \mathrm{Po}$ present in seafood could partially stem from ${ }^{226} \mathrm{Ra}$ contained in formation water found during operations in offshore production platforms. ${ }^{210} \mathrm{~Pb}$ and ${ }^{210} \mathrm{Po}$ are highly radiotoxic and present in relatively high concentrations in the marine biota due to their enhanced bioaccumulation and strong affinity for binding with certain internal tissues (Díaz-Francés et al., 2012). Consequently, ${ }^{210} \mathrm{~Pb}$ and ${ }^{210} \mathrm{Po}$ are the main contributors to the radiation dose received by marine organisms as well as by humans consuming seafood. For the pair ${ }^{210} \mathrm{Po}^{210} \mathrm{~Pb}$ behavior previously described in the literature with a common pattern is thus observed: activity concentrations of ${ }^{210} \mathrm{Po}$ are greater than activity concentrations of ${ }^{210} \mathrm{~Pb}$ in marine organisms (Carvalho, 2011). Taking into consideration that the ${ }^{210} \mathrm{~Pb} /{ }^{210} \mathrm{Po}$ activity ratios in seawater are in the range 0.5-1.0 (Fowler, 2011), it is straightforward to conclude that ${ }^{210}$ Po has a higher bioaccumulative behavior than ${ }^{210} \mathrm{~Pb}$ in the marine trophic chain (Díaz-Francés et al., 2012).

Ingestion intake of natural radionuclides depends on the consumption rates of food and water and on the radionuclide concentrations. Unfortunately, although tap water was sampled in the Bakassi Peninsula, radioactivity measurements were not performed. Thus, a partial dietary pattern of people living in Bakassi localities based on their alimentary habits was elaborated, as shown in Table 3.

A global review of ${ }^{210} \mathrm{Po}$ in marine food has suggested that representative concentrations are $2.4 \mathrm{~Bq} \cdot \mathrm{kg}^{-1}$ in fish, $6 \mathrm{~Bq} \cdot \mathrm{kg}^{-1}$ in crustaceans and $15 \mathrm{~Bq} \cdot \mathrm{kg}^{-1}$ in mollusks (UNSCEAR, 2000). Representative consumption rates are $13 \mathrm{~kg} \cdot \mathrm{y}^{-1}$ of fish and $1 \mathrm{~kg} \cdot \mathrm{y}^{-1}$ each of mollusks and crustaceans, and yield a polonium intake of $52 \mathrm{~Bq} \cdot \mathrm{y}^{-1}$. In the Bakassi peninsula, seafood is the only aliment available locally. Most other food items come from Nigeria and sometimes from the continental part of Cameroon. Thus, the representative consumption rates of inhabitants of the Bakassi Penisula are $73 \mathrm{~kg} . \mathrm{y}^{-1}$ of fish and $18.25 \mathrm{~kg} \cdot \mathrm{y}^{-1}$ for shrimps, 
Table 3. Partial diet model of Bakassi based on the alimentary habits of inhabitants.

\begin{tabular}{l}
\hline Daily consumption (dry weight) \\
\hline 400 G OF TAPIOCA (CASSAVA BY- PRODUCT) \\
200 G OF FISH \\
$50 \mathrm{~g}$ of shrimps \\
$50 \mathrm{~g}$ of waterleaf \\
$50 \mathrm{~g}$ of eru leaf \\
20 G OF COWPEA \\
\hline
\end{tabular}

as shown in Table 3. These values are significantly higher than the world average values. These values come from surveys in the field and from the World Bank survey in coastal regions of Cameroon (Koppert, 1994).

Based on the daily consumption and the ${ }^{210} \mathrm{Po}$ values found in this work, using the ingestion dose coefficient of $1.2 \mu \mathrm{Sv} \mathrm{Bq}^{-1}$, a corresponding ingestion dose of $4.8 \mathrm{mSv} \cdot \mathrm{y}^{-1}$ was found for the inhabitants of the surveyed area of Bakassi Peninsula. This radiation dose is greater than the corresponding world average value of 0.7 mSv. ${ }^{-1}$ (UNSCEAR, 2000). The difference is essentially attributable to the dietary habits of the local populations, whose main items of food are sea products. It should be noted that ${ }^{210} \mathrm{Po}$ is volatile above $100{ }^{\circ} \mathrm{C}$. Thus, cooking aliments may possibly reduce ${ }^{210} \mathrm{Po}$ concentrations in foodstuffs.

The contribution of ${ }^{226} \mathrm{Ra}$ and ${ }^{210} \mathrm{~Pb}$ was not taken into account because most of their concentrations are lower than the corresponding MDCs. Activity concentrations of ${ }^{40} \mathrm{~K}$ range between $111-1880 \mathrm{~Bq} \cdot \mathrm{kg}^{-1}$ in foodstuffs. High concentrations are observed in leafy vegetables. Nevertheless, the homeostatic regulation of ${ }^{40} \mathrm{~K}$ in the human body makes a calculation of the ${ }^{40} \mathrm{~K}$ ingested dose meaningless.

\subsection{Indoor radon concentrations and corresponding inhalation dose}

Figure 3 displays the distribution of indoor radon concentrations in 15 dwellings of the Bakassi Peninsula, precisely in Jabane and Idabato. Indoor radon concentrations range between 51-4230 Bq. $\mathrm{m}^{-3}$ with respective median and average values of $907 \mathrm{~Bq} \cdot \mathrm{m}^{-3}$ and $1280 \mathrm{~Bq} \cdot \mathrm{m}^{-3}$. In a previous work in the uranium regions of Poli and Lolodorf, indoor radon concentrations range, respectively, between $29-2240$ Bq.m ${ }^{-3}$ and 24-4390 Bq.m ${ }^{-3}$ with corresponding median values of $165 \mathrm{~Bq} \cdot \mathrm{m}^{-3}$ and $331 \mathrm{~Bq} \cdot \mathrm{m}^{-3}$ and average values of 294 and 735 Bq. $\mathrm{m}^{-3}$ (Saïdou et al., 2014). Thus, dwellings in the surveyed area of Bakassi have significantly higher radon concentrations.

Considering the latest scientific data, the World Health Organization (WHO) proposed a reference level of $100 \mathrm{~Bq} \cdot \mathrm{m}^{-3}$ to minimize health hazards due to indoor radon exposure (WHO, 2009). However, if this level cannot be reached under the prevailing country-specific conditions, the chosen reference level should not exceed 300 Bq. $\mathrm{m}^{-3}$. Taking account of the new findings, the ICRP has also reduced the upper reference value for radon gas in dwellings from $600 \mathrm{~Bq} \cdot \mathrm{m}^{-3}$ to $300 \mathrm{~Bq} \cdot \mathrm{m}^{-3}$ (ICRP, 2011).

There is not yet a regulation to protect people against radon exposure in Cameroon, so reference levels fixed at

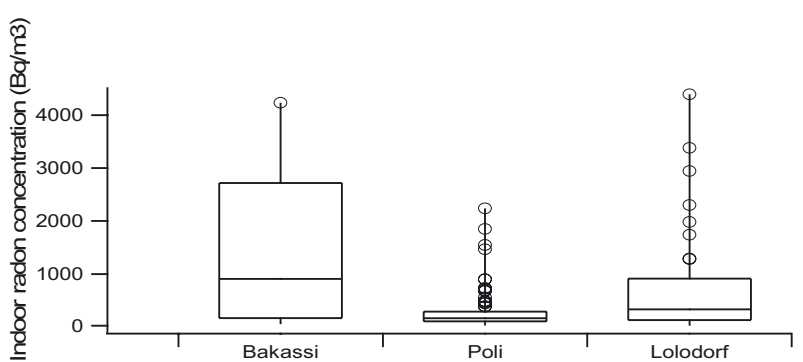

Fig. 3. Indoor radon concentrations in Bakassi compared with the regions of Poli and Lolodorf.

the international level can be used. $60 \%$ of dwellings have an indoor radon concentration above the reference level of $300 \mathrm{~Bq} \cdot \mathrm{m}^{-3}$. This level of exposure probably has an impact on human health, leading to an increase in the probability of developing lung cancer (Darby et al., 2005). The high level of indoor radon could be explained by the building construction (building materials, ventilation and floor type) because dwellings are not sufficiently ventilated. By updating the dose conversion coefficient of radon given in ICRP Publication 65 (ICRP, 1993) corresponding to $4.3510^{-6} \mathrm{mSv} /\left(\mathrm{Bqh} / \mathrm{m}^{3}\right)$, using the average indoor time (occupancy factor of 0.6) and the average radon level in dwellings of the Bakassi Peninsula, an inhalation dose of $29.3 \mathrm{mSv}^{-1}$ was calculated. This value is much higher than the world average inhalation dose of $2 \mathrm{mSv}^{-1} \mathrm{y}^{-1}$ and should be considered cautiously because measurements were performed in only 15 dwellings.

The preliminary results of this study showed that ${ }^{232} \mathrm{Th}$ concentrations in soil samples are higher than the ${ }^{238} \mathrm{U}$. Although only ${ }^{222} \mathrm{Rn}$ concentrations were measured in the surveyed area, for a proper dose assessment ${ }^{220} \mathrm{Rn}$ will be considered shortly using Raduet detectors.

Finally, as displayed in Table 4, a total dose of $34.6 \mathrm{mSv} \cdot \mathrm{y}^{-1}$ received on average by each of the 11000 inhabitants living in Jabane and Idabato was assessed following radioactivity measurements in foodstuffs, soil and indoor radon measurements in Bakassi Peninsula. This value is very high compared with the world average total dose of $3.2 \mathrm{mSv} \mathrm{y}^{-1}$, updated using the new dose conversion coefficient of radon. This difference is explained by the high level of indoor radon exposure and the dietary habits of the population of Bakassi Peninsula, having seafood, locally available, as the main aliment. In the case of confirmation of the results of this study, countermeasures must be taken into consideration to avoid such a high level of exposure, to reduce the radiation dose to the population.

\section{Conclusion}

A pilot study on radioactivity measurements in soil and foodstuff samples and indoor radon measurements was carried out in the oil-bearing region of Bakassi. Elevated indoor radon concentrations were found, and relatively high levels of ${ }^{210} \mathrm{Po}$ in seafood (fish and shrimps) and leafy vegetables were measured, yielding a high dose exposure to the public of $34.6 \mathrm{mSv} \cdot \mathrm{y}^{-1}$ compared with the world average value of $3.2 \mathrm{mSv} \cdot \mathrm{y}^{-1}$. This could be explained by the high consumption 
Table 4. Components of the total dose for members of the public in the Bakassi Peninsula; the world average inhalation dose is updated by using the new dose conversion coefficient of radon. World average values of the effective dose are taken from the UNSCEAR report (UNSCEAR, 2000).

\begin{tabular}{ccc}
\hline $\begin{array}{c}\text { Exposure } \\
\text { pathway }\end{array}$ & Location & $\begin{array}{c}\text { Effective dose } \\
\left(\mathbf{m S v} \mathbf{y}^{-\mathbf{1}}\right)\end{array}$ \\
\hline $\begin{array}{c}\text { External irradiation } \\
\text { (ground) }\end{array}$ & Bakassi & 0.27 \\
External irradiation & World & 0.5 \\
(cosmic rays) & World & 0.27 \\
Inhalation & Bakassi & 0.4 \\
& World & 29.3 \\
Ingestion & Bakassi & 4.8 \\
Total & World & 0.3 \\
\hline
\end{tabular}

of seafood and by the building construction in Bakassi. No radioactive contamination was evidenced due to the presence of offshore production platforms in the area according to radionuclide concentrations found in the surveyed area. Only 15 soil samples, 9 foodstuff samples and 15 dwellings were considered to assess radiological exposure within the framework of the present study. Thus, more data are needed for better statistical analysis of the results obtained. This will help provide an appropriate judgment of the study. Alpha spectrometry is strongly advisable for radioactivity in foodstuffs because of its low detection limit. The most urgent action is to extend the study area to all localities of Bakassi. Only after this action is carried out should recommendations to protect people against the harmful effects of natural radiation be addressed.

Acknowledgements. The Radioecology Group of the Institute of Radiation Physics of Lausanne through Pascal Froidevaux is acknowledged for radioactivity measurements in foodstuffs and manuscript improvements. Equipment used to measure radioactivity in soil was provided by the International Atomic Energy Agency (IAEA) through the Technical Cooperation project CMR/5/014 (Creation of a Radioanalytical Laboratory for Food Safety). The Swiss Federal Office of Public Health (OFSP) provided equipment for indoor radon measurements. Sébastien Baechler and Martha Palacios-Gruson are thanked for their contribution. Nguemhe Fils Salomon of the Institute of Geological and Mining Research is thanked for his contribution to presenting the study area location on the map. The Ministry of Defense of Cameroon through the BIR Delta supported transport and security during the field mission in the Bakassi Peninsula. The Institute of Geological and Mining Research partially funded the field work through the national public budget 2011. The Abdus-Salam International Centre for Theoretical Physics (ICTP) through the OEA-AC-71 is thanked for its support.

\section{References}

Agbalagba E.O., Onoja R.A. (2011) Evaluation of natural radioactivity in soil, sediment and water samples of Niger Delta (Biseni) flood plain lakes, Nigeria, J. Environ. Radioact. 102, 667-671.

Beyala Ateba J.F., Owono Ateba P., Ben-Bolie G.H., Ekobena Fouda H., Ele Abiama P., Abega C.R., Mvondo S. (2011) Determination of uranium in rocks and soil of south Cameroon by gamma spectrometry, Radioisotopes $\mathbf{6 0}, 10$.

Carvalho F.P. (2011) ${ }^{210} \mathrm{Po}$ and ${ }^{210} \mathrm{~Pb}$ in marine organisms and their transfer in marine food chains, J. Environ. Radioact. 102, 462-472.

Darby S., Hill D., Auvinen A., Barros-Dios J.M., Baysson H., Bochicchio F., Deo H., Falk R., Forastiere F., Hakama M., Heid I., Kreienbrock L., Kreuzer M., Lagarde F., Mäkeläinen I., Muirhead C., Oberaigner W., Pershagen G., Ruano-Ravina A., Ruosteenoja E., Schaffrath Rosario A., Tirmarche M., Tomásek L., Whitley E., Wichmann H.E., Doll R. (2005) Radon in homes and risk of lung cancer: collaborative analysis of individual data from 13 European case-control studies, BMJ 330, 223-229.

Díaz-Francés I., García-Tenorio R., Mantero J., Manjón G. (2012) Evaluation of the Amount of ${ }^{210}$ Po Ingested by the Spanish Population and its Relation to their Diet Habits. In: IRPA13 Proceedings.

Ele Abiama P., Owono Ateba P., Ben-Bolie G.H., Ekobena Fouda H.P., El Khoukhi T. (2010) High background radiation investigated by gamma spectrometry of the soil in the southwestern region of Cameroon, J. Environ. Radioact. 101, 739-743.

Fowler S.W. (2011) ${ }^{210}$ Po in the marine environment with emphasis on its behaviour within the biosphere, J. Environ. Radioact. 102, $448-461$.

IAEA (2003) Safety Reports Series No.34. IAEA Library Cataloguing in Publication Data. ISBN 92-0-114003-7. Vienna, Austria.

ICJ, International Court of Justice (2002) Land and Maritime Boundary between Cameroon and Nigeria. Cameroon v. Nigeria: Equatorial Guinea intervening, Judgment ICJ Reports p. 303. ISBN 92-1-070957-8.

ICRP Publication 65 (1993) Protection against radon-222 at home and at work. Pergamon Press, Oxford.

ICRP Publication 67 (1994) Age-dependant doses to members of the public from intake of radionuclides, part 2. Ingestion dose coefficients. Pergamon Press, Oxford.

ICRP Publication 69 (1995) Age-dependant doses to members of the public from intake of radionuclides, part 3. Ingestion dose coefficients. Pergamon Press, Oxford.

ICRP Publication 115 (2010) Lung Cancer Risk from Radon and Progeny and Statement on radon. Ann. ICRP 40 (1).

ICRP (2011) Radiological Protection against Radon Exposure, Draft Report for consultation. Pergamon Press, Oxford.

Jonkers G., Hartog F.A., Knaepen A.A.I., Lancee P.F.J. (1997) Characterization of NORM in the oil and gas production (E\&P) industry, Radiological Problems with Natural Radioactivity in the Non-Nuclear Industry. In: Proc. Int. Symp. Amsterdam, KEMA, Arnhem.

Koppert G.J.A. (1994) Mission du 02 au 17 Avril 1994 pour la Banque Mondiale. Les enquêtes alimentaires quantitatives entre 1950 et 1980 , qualitatives entre 1980 et 1989 , quantitatives entre 1984 et 1990 au Cameroun, Draft report.

Kotrappa P., Stieff L.R., Bigu J. (1996) Passive Rad Elec Inc E-PERM Radon Flux Monitors for measuring undisturbed radon flux from the ground. In: 1996 International Radon Symposium II.

Ngachin M., Garavaglia M., Giovani C., Kwato Njock M.G., Nourreddine A. (2007) Assessment of natural radioactivity and associated radiation hazards in some Cameroonian building materials, Radiat. Meas. 42, 61-67.

OECD (1979) Exposure to radiation from the natural radioactivity in building materials. OECD, Paris.

Saïdou, Bochud F., Laedermann J.P., Buchillier T., Kwato Njock M.G., Froidevaux P. (2007) Calibration of an HPGe detector and 
self-attenuation correction for ${ }^{210} \mathrm{~Pb}$ : Verification by alpha spectrometry of ${ }^{210} \mathrm{Po}$ in environmental samples, Nucl. Instrun. Meth. A 578, 515-522.

Saïdou, Bochud F., Laedermann J.P., Kwato Njock M.G., Froidevaux P. (2008) A comparison of alpha and gamma spectrometry for environmental radioactivity surveys, Appl. Radiat. Isotopes 66, 215-222.

Saïdou, Bochud F.O., Baechler S., Kwato Njock M.G., Ngachin M., Froidevaux P. (2011) Natural radioactivity measurements and dose calculations to the public: case of the uranium-bearing region of Poli in Cameroon, Radiat. Meas. 46, 254-260.
Saïdou, Abdourahimi, Tchuente Siaka Y.F., Bouba O. (2014) Indoor radon measurements in the uranium regions of Poli and Lolodorf Cameroon, J. Environ. Radioact. 136, 36-40.

UNSCEAR (1993) Sources and effects of ionizing radiation. United Nations publication, New York.

UNSCEAR (2000) Sources and effects of ionizing radiation. United Nations publication, Vienna, Austria.

WHO (2009) Handbook on Indoor Radon, a public health perspective. Library Cataloguing-in-Publication Data, Geneva.

Cite this article as: Saïdou, Abdourahimi, Y.F. Tchuente Siaka, M.G. Kwato Njock. Natural radiation exposure to the public in the oilbearing Bakassi Peninsula, Cameroon. Radioprotection 50(1), 35-41 (2015). 